\title{
Effects of Calcium Hopantenate on Neurotransmitter Receptors in the Rat Brain
}

\author{
Norio OGAWA, Itaru NUKINA*, Yukiko HIROSE, \\ Masato FUKUSHIMA and Akitane MORI \\ Department of Neurochemistry, Institute for Neurobiology. \\ and *Third Department of Interna! Medicine, Okayama University Medical School. \\ 2-5-1 Shikatacho. Okayama 700, Japan
}

Accepted September 25, 1984

\begin{abstract}
Effects of calcium hopantenate (HOPA) on neurotransmitter and neuropeptide receptors in the central nervous system (CNS) were investigated. In the radioreceptor assay (RRA), HOPA inhibited the $\left[{ }^{3} \mathrm{H}\right]$ - $\gamma$-aminobutylic acid (GABA) receptor binding in a dose-dependent manner with a cross-reactive potency of $0.2 \%$. On the other hand, radiolabeled ligand binding to CNS receptors in the benzodiazepine (BDZ)-, musucarinic cholinergic (mACh)-, methionine-enkephalin (ENK) - and thyrotropin releasing hormone (TRH)-RRA systems was not inhibited even by the addition of HOPA up to $100 / \mathrm{M}$. Repeated injection of HOPA (250 $\mathrm{mg} / \mathrm{kg} /$ day for 7 consecutive days) increased GABA receptor binding by $53 \%$ in the cerebral cortex, while GABA binding in the rest of the forebrain did not change. The increased GABA receptor binding in the cerebral cortex of HOPA treated rats was due to the increased affinity of the binding sites. BDZ-, mACh-, ENK- and $\mathrm{TRH}$-receptor bindings were not affected in either the cerebral cortex or the rest of the forebrain by repeated injection of HOPA. These results suggest that at least a part of the therapeutic efficacy of HOPA is due to sensitization of the GABA receptor in the cerebral cortex.
\end{abstract}

Calcium hopantenate (HOPA), designated chemically as calcium D-(+)-4-(2,4-dihydroxy-3,3-dimethylbutyramido) butyrate hemihydrate, is a $r$-aminobutyric acid (GABA) derivative wherein the $\beta$-alanine of pantothenic acid has been substituted by GABA. HOPA has been used clinically in the treatment of hyperkinesia, hypoprosexia, speech disturbance and hypobulia all accompanying either mental retardation, postencephalitis or cerebral palsy $(1,2)$. The drug is also reported to be effective for promoting the uptake of glucose into the brain (3) and improving EEG abnormalites (4-6), in addition to its therapeutic applicability to organic mental disorders in the aged $(7,8)$. It was shown by us that HOPA can improve experimental traumatic disturbance of consciousness in mice (9). However, a mechanism which explains the effects of HOPA on the central nervous system (CNS) has not been fully elucidated. Although HOPA contains GABA within its structure, GABA is not liberated after HOPA's distribution into the brain $(10,11)$, and HOPA has been reported to have no GABAlike action (12). In the present study, the effects of HOPA on various neurotransmitter receptors of the rat brain were examined.

Five kinds of CNS receptors were examined: (a) GABA receptors, because HOPA is a GABA derivative, (b) benzodiazepine (BDZ) receptors which are closely related to GABA receptors, (c) muscarinic acetylcholine ( $\mathrm{mACh}$ ) receptors which are strongly related to dementia, (d) methionineenkephalin (ENK) receptors which are closely related to emotion and pain, and (5) thyrotropin releasing hormone $(\mathrm{TRH})$ receptors which participate closely in emotion and consciousness. 


\section{Materials and Methods}

Animals used were male Sprague-Dawley rats weighing 200-225 g. HOPA (Hopate ${ }^{R}$ ) was donated by Tanabe Seiyaku Co., Ltd., Osaka, Japan. HOPA used in this study contained a trace amount $(0.005 \%)$ of GABA. $\left[{ }^{3} \mathrm{H}\right] \mathrm{GABA}$ (specific activity $57 \mathrm{Ci} / \mathrm{mmol}$ ), $\left[{ }^{3} \mathrm{H}\right.$ ] quinuclidinyl benzilate (QNB) (specific activity $12 \mathrm{Ci} / \mathrm{mmol}$ ) and $\left[{ }^{3} \mathrm{H}\right] \mathrm{ENK}$ (specific activity $51 \mathrm{Ci} / \mathrm{mmol}$ ) were purchased from Radiomedical Center, Amersham, U.K. $\left[{ }^{3} \mathrm{H}\right]$ diazepam (specific activity $90 \mathrm{Ci} / \mathrm{mmol}$ ) and $\left[{ }^{3} \mathrm{H}\right] \mathrm{TRH}$ (specific activity $90 \mathrm{Ci} / \mathrm{mmol}$ ) were purchased from New England Nuclear Co., Boston, MA.

The in vitro effect of HOPA on neurotransmitter receptors was evaluated with a radioreceptor assay (RRA) in which the crude synaptic membrane fraction $\left(P_{2}\right.$ fraction) obtained from the whole brain was used as the receptor preparation. Procedures of RRAs for GABA $(13,14)$, BDZ (diazepam) (15), mACh (QNB) (16), ENK (17) and TRH $(18,19)$ have been reported previously.

To elucidate the in vivo effect of HOPA on CNS receptors, $250 \mathrm{mg} / \mathrm{kg}$ HOPA was administered intraperitoneally once a day for seven successive days. Then, the cerebral cortex or the rest of the forebrain was homogenized in Tris- $\mathrm{HCl}$ buffer $(50 \mathrm{mM}$ Tris- $\mathrm{HCl}, \mathrm{pH}$ 7.6) according to previous methods $(15,17,19)$ to prepare the particulate fraction for determining the change in each receptor by RRA. Rats which received physiological saline intraperitoneally for seven days served as controls.

The change in each receptor was assessed by the change in specific binding. A saturation experiment was carried out on receptors which showed statistically significant changes, and the data were analyzed by Scatchard plots using a computer (NEC sytem PC-8800) in accordance with the nonlinear regression method of Marquedt's report (20).

\section{Results}

1. In vitro effect of HOPA on CNS receptors: Since HOPA is a GABA derivative, its action on the in vitro GABA-RRA system was investigated first. The result is shown in Fig. 1. HOPA inhibited the $\left[{ }^{3} \mathrm{H}\right] \mathrm{GABA}$ GABA receptor binding in a dose-dependent manner. Its dilution curve was parallel to the standard curve of $\mathrm{GABA} . \mathrm{CaCl}_{2}$ was added up to 100 " $\mathrm{M}$, but the binding was not affected, thus the result was not found to be due to calcium ions from HOPA. Furthermore, a Lineweaver-Burk plot clarified that HOPA had a competitive action on the GABA binding site (Fig. 2). This finding suggests that HOPA acts directly on GABA receptors. However, when various GABA derivatives were examined in the GABA-RRA system to determine their $50 \%$ inhibitory concentration

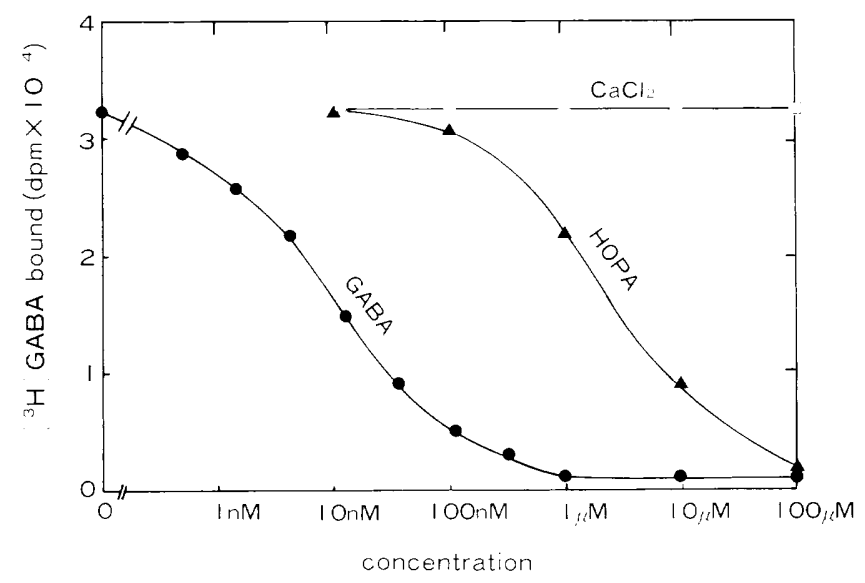

Fig. 1. Effects of GABA. HOPA and $\mathrm{CaCl}_{2}$ on binding of $\left[{ }^{3} \mathrm{H}\right] \mathrm{GABA}$ to crude synaptic membranes of the rat brain. A. HOPA; $\square, \mathrm{CaCl}_{2}$. 
(IC50) on $\left[{ }^{3} \mathrm{H}\right] \mathrm{GABA}-\mathrm{GABA}$ receptor binding, the cross-reactive potency of HOPA was only $0.2 \%$ in terms of the specific potency of GABA binding, taken as $100 \%$. This crossreactive potency of HOPA in GABA-RRA was 40 times higher compared with GABA concentration in HOPA $(0.005 \%)$ which we used in this study. The inhibitory potency of HOPA was one five hundredth times as low as that of GABA, indicating that the potency of HOPA was lower than that of the other GABA derivatives (Table 1). Labeled ligand binding to CNS receptors in the BDZ-, mACh-, ENK- and TRH-RRA systems was not inhibited even by the addition of HOPA up to $100 \mu \mathrm{M}$.

2. Effect of repeated administration of HOPA on CNS receptors: Figure 3 shows the result of specific binding of each receptor of rat cerebral cortex after intraperitoneal administration of HOPA (250 mg/ $\mathrm{kg} /$ day) for 7 consecutive days. Five types of RRA were performed using the same sample. Only GABA receptors of HOPA treated rats increased $53 \%$ compared with those of the control. The other four receptors, BDZ-,

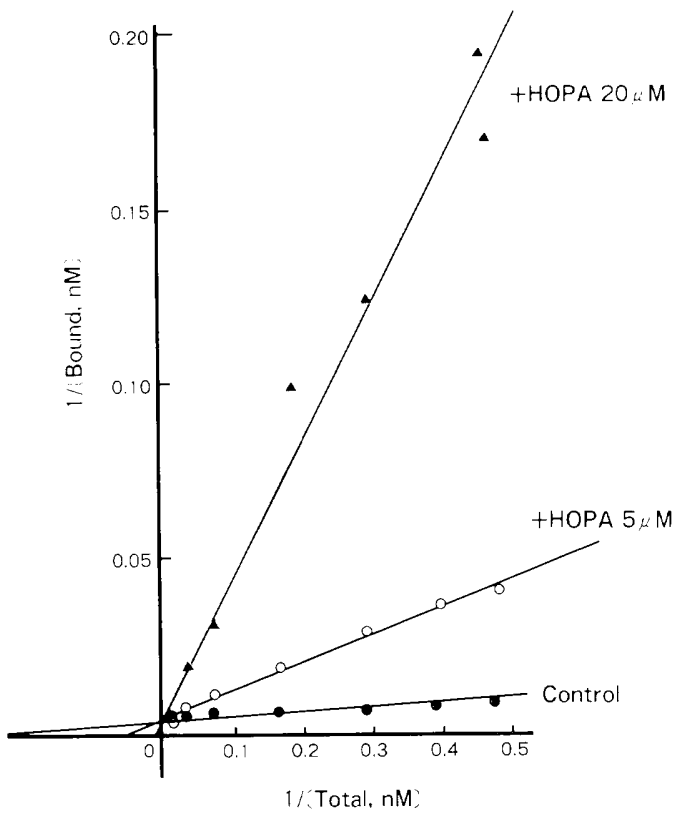

Fig. 2. Lineweaver-Burk plot of the GABA-RRA. Values are the mean of duplicate determinations. Control GABA-RRA (-) and GABA-RRA in the presence of $5 \% \mathrm{M} \mathrm{HOPA}(O)$ or $20 \% \mathrm{MHOPA}(\boldsymbol{A})$.

Table 1. Relative potency of GABA related compounds in GABA-RRA

\begin{tabular}{|c|c|c|}
\hline Name & Chemical structure & $\begin{array}{c}\text { Potency } \\
\text { in GABA-RRA (\%) }\end{array}$ \\
\hline GABA & $\mathrm{H}_{2} \mathrm{NCH}_{2} \mathrm{CH}_{2} \mathrm{CH}_{2} \mathrm{COOH}$ & 100.0 \\
\hline Homotaurine & $\mathrm{H}_{2} \mathrm{NCH}_{2} \mathrm{CH}_{2} \mathrm{CH}_{2} \mathrm{SO}_{3} \mathrm{H}$ & 87.5 \\
\hline Homohypotaurine & $\mathrm{H}_{2} \mathrm{NCH}_{2} \mathrm{CH}_{2} \mathrm{CH}_{2} \mathrm{SO}_{2} \mathrm{H}$ & 16.3 \\
\hline$d-G A B O B$ & $\mathrm{H}_{2} \mathrm{NCH}_{2} \mathrm{CH}(\mathrm{OH}) \mathrm{CH}_{2} \mathrm{COOH}$ & 10.0 \\
\hline 3-Guanidinopropanoic acid & $\mathrm{H}_{2} \mathrm{NC}(\mathrm{NH}) \mathrm{NHCH}_{2} \mathrm{COOH}$ & 3.7 \\
\hline 3-Hydroxyhomotaurine & $\mathrm{H}_{2} \mathrm{NCH}_{2} \mathrm{CH}(\mathrm{OH}) \mathrm{CH}_{2} \mathrm{SO}_{3} \mathrm{H}$ & 3.5 \\
\hline $1-\mathrm{GABOB}$ & $\mathrm{H}_{2} \mathrm{NCH}_{2} \mathrm{CH}(\mathrm{OH}) \mathrm{CH}_{2} \mathrm{COOH}$ & 2.3 \\
\hline Guanidinoacetic acid & $\mathrm{H}_{2} \mathrm{NC}(\mathrm{NH}) \mathrm{NHCH}{ }_{2} \mathrm{COOH}$ & 2.1 \\
\hline GABA-choline & {$\left[\mathrm{H}_{2} \mathrm{NCH}_{2} \mathrm{CH}_{2} \mathrm{CH}_{2} \mathrm{COOCH}_{2} \mathrm{~N}^{+}\left(\mathrm{CH}_{3}\right)_{3}\right] \mathrm{Cl}^{-}$} & 2.0 \\
\hline 5-Aminovaleric acid & $\mathrm{H}_{2} \mathrm{NCH}_{2} \mathrm{CH}_{2} \mathrm{CH}_{2} \mathrm{CH}_{2} \mathrm{COOH}$ & 1.1 \\
\hline 4-Amino-4-methylvaleric acid & $\mathrm{H}_{2} \mathrm{NC}\left(\mathrm{CH}_{3}\right)_{2} \mathrm{CH}_{2} \mathrm{CH}_{2} \mathrm{COOH}$ & 0.7 \\
\hline$\beta$-Ethylthio-GABA & $\mathrm{H}_{2} \mathrm{NCH}_{2} \mathrm{CH}\left(\mathrm{SC}_{2} \mathrm{H}_{5}\right) \mathrm{CH}_{2} \mathrm{COOH}$ & 0.7 \\
\hline 3-Amino-2-hydroxyhomotaurine & $\mathrm{H}_{2} \mathrm{NCH}_{2} \mathrm{CH}(\mathrm{OH}) \mathrm{CH}_{2} \mathrm{SO}_{2} \mathrm{H}$ & 0.5 \\
\hline$\beta$-Alanine & $\mathrm{H}_{2} \mathrm{NCH}_{2} \mathrm{CH}_{2} \mathrm{COOH}$ & 0.3 \\
\hline Taurine & $\mathrm{H}_{2} \mathrm{NCH}_{2} \mathrm{CH}_{2} \mathrm{SO}_{3} \mathrm{H}$ & 0.2 \\
\hline \multirow[t]{2}{*}{ Homopantothenic acid } & $\mathrm{H}-\mathrm{NCH}_{2} \mathrm{CH}_{2} \mathrm{CH}_{2} \mathrm{COOH}$ & 0.2 \\
\hline & $\mathrm{COCH}(\mathrm{OH}) \mathrm{C}\left(\mathrm{CH}_{3}\right)_{2} \mathrm{CH}_{2} \mathrm{OH}$ & \\
\hline
\end{tabular}

Relative potency in, GABA-RRA was calculated from the concentration of the compound that inhibited specific binding by 50\% (IC50). Each 1 C50 determination used 7-9 concentrations of each compound in triplicate. As a competitor. $6.4 \mathrm{nM}\left[{ }^{3} \mathrm{H}\right] \mathrm{GABA}$ was present. The results were converted to specific binding ard plotted or log-probit paper so that the concentration giving $50 \%$ binding could be read. 


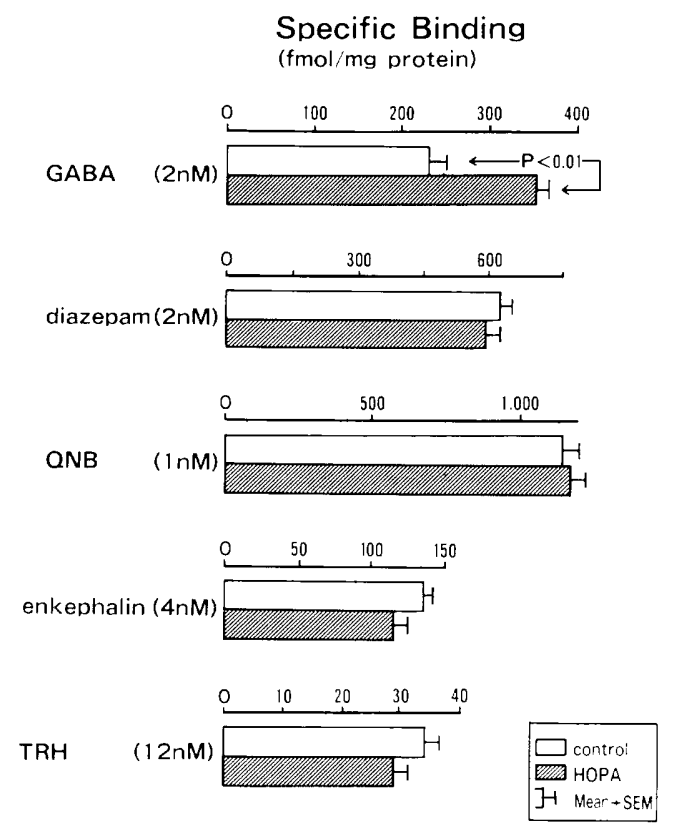

Fig. 3. Effects of repeated injection of HOPA on GABA-, diazepam-, QNB-, enkephalin- and TRHreceptor bindings of rat cerebral cortex. The number in parenthesis indicates the concentration of radiolabeled ligands used. The specific binding was expressed by the binding difference in the presence and absence of an excess amount of unlabeled ligands: and $1 \mathrm{mM}$ GABA, $1 \mu \mathrm{M}$ diazepam, $1 \mu \mathrm{M}$ atropine, $10 \mu \mathrm{M}$ ENK or $100 \mu \mathrm{M}$ TRH was used as the excess unlabeled ligand, respectively. The data are shown as the mean + S.E.M. of 5 rats. Statistica! significance is calculated by one-way ANOVA.

mACh-, ENK- and TRh-receptors, remained unchanged (Fig. 3). In order to elucidate the mechanism of increase in specific binding of GABA receptors, Scatchard analysis of GABA binding in cerebral cortex was done (Fig. 4). The result proved that the increased GABA receptor binding in the cerebral cortex of HOPA treated rats was due to the increased affinity of the binding sites. However, all five, GABA-, BDZ-, mACh-, ENK- and TRHreceptor, bindings of the rest of the forebrain (forebrain minus cerebral cortex) of HOPA treated rats remained unchanged.

\section{Discussion}

Although HOPA has been used in the clinical field as a drug acting on the CNS (1-

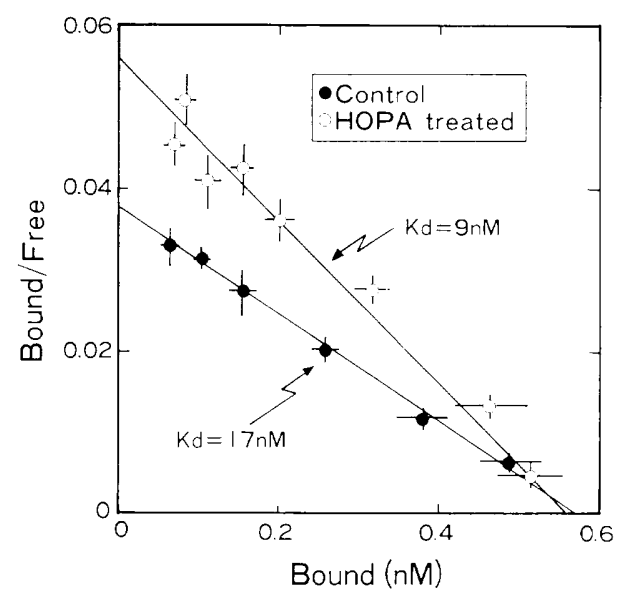

Fig. 4. Scatchard plot of GABA receptor binding of the cerebra! cortex obtained from control (O) arid HOPA-treated $(O)$ rats. Points are expressed as the mean \pm S.E.M. of three experiments.

8), little work has been done to study it fundamentally so as to obtain a sufficient explanation of its therapeutic effects. The chemical structure of HOPA resembles that of GABA, but GABA is not liberated from HOPA after the uptake of HOPA in the brain $(10,11)$. Even though HOPA is administered for a week in rats, the concentrations of GABA and other amino acids in the brain remain unchanged (3). Furthermore, the brain amine levels are not influenced by HOPA administration (3). HOPA is known to have neither GABA-like action nor GABA-antagonistic action in a bioassay system using crayfish opener muscle (12). The results obtained in the present study substantiate the evidence that HOPA can act directly on GABA receptors (Figs. 1 and 2). HOPA is hardly metabolized and is excreted into the urine almost intact structurally $(10,11)$. Therefore, unlike GABA, the action of HOPA continues for a longer period, resulting in a possibly greater action on the CNS, even though the cross-reactive potency in the RRA is small. The binding of $B D Z$ receptors increases in the presence of GABA-like substances $(21,22)$. As shown in our previous paper (13), since the binding of $B D Z$ receptors also increases in the presence of HOPA as with GABA, the mechanism of action of HOPA may be interpreted as being similar to that of GABA. 
The result obtained by the RRA was different from that obtained by bioassay using crayfish opener muscle. However, it has already been reported that as far as GABA receptors are concerned, there are some differences between the results obtained by these two methods (23). In addition, since central nervous cells are used in the RRA while peripheral tissue is used in the bioassay. there may exist a difference in histologic susceptibility between the two methods. Species differences may also influence the results. Therefore, these differences must be taken into consideration in further studies.

When HOPA was injected for seven consecutive days, only the GABA receptors of the cerebral cortex increased by $53 \%$ compared with the control level. The other four neurotransmitter receptors remained unchanged after injection of HOPA. In general, the membrane receptors of a hormone decrease when the corresponding hormone level rises continuously, which is known as the down regulation phenomenon (24). This phenomenon also occurs generally in neurotransmitter receptors after administration of the agonist. However, receptors for prolactin and angiotensin are reported to be increased by homologous hormones (24). HOPA is believed to be a GABA-like drug from the results of the RRA as described above, and increase in affinity of GABA receptors for GABA occurs by successive injection of HOPA. Therefore, HOPA has a unique action mechanism as a CNS acting drug, and it may regulate $G A B A$ receptors in the same manner as prolactin and angiotensin do. The action of chronic administration of HOPA in increasing the GABA receptor affinity seems to be the principal mechanism of action in the CNS. All findings in this study suggest that HOPA has a possible therapeutic use in the treatment of CNS dysfunctions associated with abnormalities of the CNSGABAergic system.

Acknowledgement: This work was supported in part by grants from the Ministry of Education. Science and Culture and the Ministry of Health and Welfare of the Japanese Government.

\section{References}

1 Task Force for Evaluation of Children's
Behaviours: A double-blind controlled study of $\mathrm{Ca}$ hopantenate and pyrithioxine in conformity to a rating list for the evaluation of the abnormal behaviours in children. Clin. Eval. 2, 335-364 (1974) (Abs. in English)

2 Okada, R. and Sasaki, T.: The effect of Cahopantenate on the autistic children. SeishinIgaku 22, 81-91 (1980) (in Japanese)

3 Danno, T., Matsuoka, Y., Morita, T., Takahashi, T., Sugihara, S.. Kakimoto, T., Takie, Y. and Shibatani, T.: Biochemical study of calcium hopantenate (HOPA). In Reports of Tanabe Seiyaku Research Laboratories, p. 99-106. Tanabe Seiyaku, Osaka (1978) (in Japanese)

4 Nishizawa, Y., Kodama, T. and Tsujino, G.: Effect of $\gamma$-aminobutyric acid derivatives. especially, homopantothenic acid, on excitability of the brain. J. Vitaminol. 14, 331-344 (1968)

5 Nishizawa, Y., Kodama, R., Ishida, R., Adachi, S. and Kowa, Y.: Electrophysiological investigations of homopantothenic acid. J. Vitaminol. 14, 345353 (1968)

6 Hamamoto, E.: Studies on electroencephalogram in children with special reference to the effect of homopanthenic acid on mentally retarded children. Proc. Japan. Acad. 42, 853-862 (1966)

7 Kaneda, H., Yagasaki, A., Kobayashi, T. and Nishimura, T.: The clinical effect of $\mathrm{Ca}$-hopantenate on cerebral organic mental disorders in senile and middle-aged stage. Geriatr. Med. (Tokyo) 18, 1433-1448 (1980) (in Japanese)

8 Atarashi, J. and Otomo, E.: Clinical evaluation of HOPA in the treatment of cerebrovascular disorders. Clin. Eval. 9, 673-710 (1981) (Abs. in English)

9 Ogawa, N., Tsukamoto, S., Mizuno, S., Shindo, S. and Mori, A.: Effects of calcium hopantenate on concussion followirig head injury in mice. IRCS Med. Sci. 10, 512-513 (1982)

10 Kodama. T., Meshi, T. and Sato, Y.: Studies on homopantothenic acid (IV). Uptake of homopantothenic acid by rat brain. Vitamins (Japan) 33, 615-619 (1966) (Abs. in Erig!ish)

11 Nakamura, S., Takahashi, T. and Sato, Y.: Studies on the distribution of radioisotopes by whole body autoradiography $(X X X)$. The fate of ${ }^{14} \mathrm{C}-$ HOPA in rats and mice. Vitamins (Japan) 45, 193-200 (1972) (Abs. in English)

12 Tabuchi, T. and Nakajima, H.: Studies on calcium hopantenate in the crayfish opener muscle. Pharmacometrics 24, 617-623 (1982) (Abs. in English)

13 Ogawa, N., Tsukamoto, S., Yokoi, I., Mizuno, S. and Mori, A.: Effects of hopantenic acid on 
brain GABA receptors and experimentat seizures. Neurosciences (Kobe) 8, 311-321 (1982)

14 Kuroda, H., Ogawa, N., Nukina, I. and Ota, Z: An endogenous inhibitor of GABA receptor binding. Neurochem. Res. 9, 21-27 (1984)

15 Mizuno, S., Ogawa, N. and Mori, A.: Superhigh-affinity binding site for $\left[{ }^{3} \mathrm{H}\right]$ diazepam in the presence of $\mathrm{CO}^{2+}, \mathrm{Ni}^{2+}, \mathrm{Cu}^{2+}$, or $\mathrm{Zn}^{2+}$. Neurochem. Res. 7, 1487-1493 (1982)

16 Ogawa, N., Mizuno, S., Nukina, I.. Tsukamoto, S. and Mori, A.: Chronic thyrotropin releasing hormone (TRH) administration on TRH receptors and muscarinic cholinergic receptors in CNS. Brain Res. 263, 348-350 (1983)

17 Ogawa, N., Yamawaki, Y., Kuroda, H. and Ofuji, T.: Effects of bromocriptine on receptor binding of methionine-enkephalin. Neurosci. Lett. 23, 215-218 (1981)

18 Ogawa, N., Yamawaki, Y., Kuroda, H., Ofuji, T., Itoga, E. and Kito, S.: Discrete regional distribution of thyrotropin releasing hormone $(\mathrm{TRH})$ receptor binding in monkey central nervous system. Brain Res. 205, 169-174 (1981)

19 Ogawa, N., Yamawaki, Y., Kuroda, H., Nukina,
I., Ota, Z., Fujino, M. and Yanaihara, N.: Characteristics of thyrotropin releasing hormone $(\mathrm{TRH})$ receptors in rat brain. Peptides $3,669-$ 677 (1983)

20 Marquardt, D.W.: An algorithm for least-squares estimation of nonlinear parameters. J. Soc. Indust. Appl. Math. 11, 431-441 (1963)

21 Tallman, J.F., Thomas, J.W. and Gallager, D.W.: GABAergic modulation of benzodiazepine biriding site sensitivity. Nature 274, 383-385 (1978)

22 Chiu, T.H. and Rosenberg, H.C.: GABA receptor-mediated modulation of ${ }^{3} \mathrm{H}$-diazepam binding in rat cortex. Eur. J. Pharmacol. 56, 337345 (1979)

23 Roberts, E., Kranse, D.N., Wong, E. and Mori, A.: Different efficacies of $d$ - and $1-\gamma$-amino- $\beta$ hydroxybutyric acid in GABA receptor and transport test system. J. Neurosci. 1, 132-140 (1981)

24 Van Obberghen, E. and Roth, J.: The insulin receptors and its function. In Receptor Regulation, Edited by Lefkowitz, R.J., p. 7-40. Chapman and Hall, London and New York (1981) 